\title{
Derleme
}

\section{Diş çürüğünün tedavisinde ozon uygulamaları}

\author{
Didem Atabek \\ Pedodonti Anabilim Dalı, Gazi Üniversitesi \\ Diş Hekimliği Fakültesi, Ankara, Türkiye
}

\begin{abstract}
ÖZET
Son yıllarda 'diş hekimliğinde koruyucu yaklaşımlar' ya da 'invaziv olmayan yaklaşımlar' kapsamında yeni bir tedavi modeli olarak ozon uygulamaları gündeme gelmiştir. Ozon molekülünün varlığı sonucu oluşan oksidasyon reaksiyonu, ozonu bakterilerin hücre duvarlarını ve hücre çeperlerini okside ederek yok eden, çok güçlü bir biyosidal ajan haline dönüştürmektedir. Oluşturulan bu derlemenin amacı, ozonun temel özelliklerinin tanıtılması ve diş hekimliğinin temelini oluşturan çürük dinamiği üzerine etkisi ve çürük tiplerine göre kullanımı hakkında bilgi sunmaktır.
\end{abstract}

AnAHTAR Kelimeler: Diş çürükleri; diş remineralizasyonu; Ozon

KAYNAK Göstermek İçin: Atabek D. Diş çürüğünün tedavisinde ozon uygulamaları. Acta Odontol Turc 2014;31(3):149-53.

[Abstract in English is at the end of the manuscript]

\section{Giriş}

Ozon, atmosferin üst tabakalarında üretilen ve havadan daha ağır olduğu için yer çekiminin etkisi ile dünyaya doğru inerken kirli atıklarla reaksiyona girerek havayı temizleyen bir gazdır. Ozonun oluşumu, moleküler oksijenin $\left(\mathrm{O}_{2}\right)$ ışıksal ayrışma reaksiyonu sonucu iki aktif atomik oksijene $(\mathrm{O})$ dönüştürülmesi ile gerçekleşmektedir. Bu işlem için yüksek enerji gerekmektedir ve enerji kaynağı ultraviole (UV) ışını, kimyasal ya da elektriksel olabilmektedir. Aktif $O$, bir bileşik oluşturmak için partner arar ve $\mathrm{O}_{2}$ bulunan ortamda ozon gazı $\left(\mathrm{O}_{3}\right)$ oluşmaktadır. Reaksiyon sunucunda \%95'ten az $\mathrm{O}_{2}$ ve $\% 5$ 'ten fazla ozon içeren bir gaz karışımı elde edilmektedir. $^{1}$

Ozon gazı, oksijene göre 1.6 kat daha yoğun ve suda 10 kat daha fazla çözülebilir bir gazdır. Radikal bir

\footnotetext{
Makale gönderiliş tarihi: 29 Ocak 2014; Yayına kabul tarihi: 03 Nisan 2014 *iletişim: Didem Atabek, Pedodonti Anabilim Dalı, Gazi Üniversitesi

Diş Hekimliği Fakültesi, Ankara, Türkiye;

e-posta: dtdidem@ hotmail.com
}

molekül olmamasına rağmen, fluorid ve persülfattan sonraki üçüncü en potansiyel oksitleyici moleküldür. Kararsız bir gaz olduğundan saklanamamakta ve üretildiği anda kullanılması gerekmektedir. Oluşan ozon molekülü, enerjisini serbest bıraktığı anda hızla ekzotermik bir reaksiyonla $\mathrm{O}_{2}$ molekülü ve O'ya dönüşmekte ve bu yapının ayrışması sonucunda $\mathrm{OH}$ radikalleri ve $\mathrm{O}_{2}$ meydana gelmektedir. ${ }^{1-3}$

Ozon molekülünün kaynaklarına ve biyolojik özelliklerine bakıldığında, tedavi amacı ile doğru dozaj ve konsantrasyonda kullanımının güvenli, etkili ve yan etkisiz olduğu düşünülmektedir. ${ }^{3}$ Düşük konsantrasyonlarda klorin bazlı dezenfektanlara göre 150 kat daha etkili olması, 3500 kat daha hızlı etki sağlaması ve birçok dezenfektanın karakteristik özelliği olan tat ya da kötü koku gibi yan etkilerin olmaması, ozon ile sağlanan dezenfeksiyonunun avantajları arasında sıralanmaktadır. ${ }^{4}$ Öte yandan ozonun doğru dozaj ve konsantrasyonda kullanılmadığı takdirde özellikle solunum sistemi için oldukça toksik bir molekül olduğu bildirilmiştir. Birleşmiş Milletler Mesleki Güvenlik ve Sağlık İdaresi (Occupational Safety and Health Administration; OSHA) terapötik amaçla ozon kullanımının güvenlik limitlerini 0.06 ppm 8 saat/gün; 0.3 ppm 15 dakika/5-7 gün olarak belirlemiştir. ${ }^{4}$

\section{Ozonun diş hekimliği alanında kullanımı}

Diş hekimliği uygulamalarına yönelik olarak üretilen ilk ozon jeneratörü HealOzone (Kavo, Almanya) 2100 ppm, $\% 0.052$ ve havadaki oranı $13.3 \mathrm{ml} / \mathrm{sn}$ konsantrasyonda ozon üretmektedir. Sistem oluşturduğu ozonu tedavi sahasına, el aletine takılan dişi vakumlayarak kavrayan silikon tek kullanımlık başlıklar aracılığı ile göndermektedir. Vakumlama işlemi gerçekleşmediği takdirde, sistem çalışmaya başlamamakta ve ozon üretimi yapmamaktadır. 1,4,5 Diş hekimliğinde ozon kullanımına yönelik olarak geliştirilen bir diğer cihaz Ozi-cure/Ozonytron (Biozonix, Almanya), daha düşük konsantrasyonlarda ozon üreten, vakumlama yapan ya da kavrayıcı kontrollü bir yapı olmadan tedavi sahasına doğrudan ozonu gönderen bir sistemdir. ${ }^{4,5}$

Millar ve Hodson ${ }^{4}$ piyasada yer alan her iki sistemden kaviteye yönelik ve endodontik uygulamalar sırasında sızan hava içerisindeki ozon seviyesini farenks, burun açıklığı ve klinik uygulamacının ağız çevresi alan- 
larında, ozon metre kullanarak in vitro bir çalışma ile değerlendirmişlerdir. Sonuçta tüm alanlardaki HealOzone sisteminden sızan ozon seviyesi sıfır olarak bulgulanırken; Ozi-cure uygulaması sonrasında izin verilen limitlerden yüksek seviyelerde ozon varlığı bulgulanmıştır. Aynı çalışmada HealOzone sisteminde yer alan vakumlama sisteminin okluzal, bukkal, lingual ve palatal yüzeyler için kullanışlı ve güvenli olduğunu, ancak aproksimal yüzeylere ya da periodontal alanlara uygulamanın zor olabileceği rapor edilmiştir.

Çürük lezyonlarının tedavisinde ozon uygulamaları sonrasında gerçekleşen remineralizasyon sürecinin takibi genellikle DIAGNOdent (Kavo) kullanılarak yapılmaktadır. Birçok araştırmacı ozon uygulamala- rının etkinliğinin takibinde DIAGNOdent kullanımının geçerliliğini histolojik kesit, elektron çürük monitörü (ECM) ya da klinik gözlem indeksi (CSI) değerlendirmeleri ile karşılaştırmıştır. Sonuçlar, uygulama sonrası takip zamanlarında DIAGNOdent değerlerinde anlamlı düzeyde azalma gözlendiğini, DIAGNOdent ölçümleri ile histolojik kesitler, ECM ya da CSI skorları arasında korelasyon olduğunu belirtmektedir..$^{5-7}$ Öte yandan Bader ve Shugars $^{8}$ DIAGNOdent kullanımı ile ilgili yaptıkları derlemede, yöntemin klinik ve radyografik değerlendirmelerle birlikte kullanılması gerektiğini, cihazın çürük dokuları belirlemede yüksek duyarlılık gösterse de; sağlam dokuları çürük olarak algılayabileceğini yani düşük özgüllük değerleri gösterdiğini rapor etmiştir. Lussi ve ark. ${ }^{9}$ yürütülen çalışmalarla benzer şekilde, DIAGNOdent ölçümlerinin CSI skorları ile desteklenmesi gerektiğini belirtmiştir.

\section{Çürük lezyonlarının tedavisi}

Ozon molekülünün varlığı sonucu oluşan oksidasyon reaksiyonu, ozonu bakterilerin hücre duvarlarını ve hücre çeperlerini okside ederek yok eden, çok güçlü bir biyosidal ajan haline dönüştürmektedir. ${ }^{10-14}$

Ozon, güçlü okside edici özelliği sayesinde çürük lezyonunu koruyan protein tabakayı ortadan kaldırmakla birlikte, bakterisidal bir etki de göstermektedir. Çürük lezyonundaki bakteri popülasyonu üzerinde ciddi yok edici bir etki yapılarak, metabolik dengenin remineralizasyon yönüne dönmesini sağlamaktadır. Bunun sonucunda, herhangi bir karyojenik bakteri ve ekolojik ortamın remineralizasyon sonrası lezyon içerisine girmesi mümkün olmamaktadır. Bakteriler tarafından üretilen ve çürük lezyonunun ilerlemesinde etkili olan pirüvik asit, ozon tarafından okside edildiğinde asetat ve karbon dioksit oluşmaktadır. Asetat, pirüvik aside göre daha alkalen bir yapıya sahiptir ve dekarboksilasyon reaksiyonu sonucu oluşan alkalen ortam sayesinde, çürük lezyonu içerisine mineral yığılımı kolaylaşmaktadır. Ozon uygulaması sonrası remineralizasyon sürecini başlatmak için ampul şeklindeki remi- neralize edici solüsyon preparatları ( $\mathrm{pH}$ Balancer, CureOzone, Kavo, ABD) üretici firmanın önerisi doğrultusunda uygulanabilmektedir. ${ }^{1,15}$ Ozon tedavisi uygulanır uygulanmaz, ortam tükürükle temas ettiğinde, lezyon normal ağız içi bakteri popülasyonu ile kaplanmaktadır. Bu ortamda bakteriler çürük ilerlemesine sebep olan asidik ürünler oluşturamamaktadırlar ve iyi bir ağız hijyenine sahip bireyin tükürüğünde var olan mineralize edici yapılar remineralizasyon için yeterlidir. ${ }^{15-17}$

\section{Süt dişi çürük lezyonlarının tedavisi}

Süt dişlerinde çürük lezyonlarının tedavisinde, ozon uygulamasının ardından Cam iyonomer simanların (CIS) kullanımı günümüz modern diş hekimliğinde önemli bir tedavi yaklaşımı olarak kabul edilmektedir. Çürük lezyonunun bulunduğu bölgedeki yumuşak eklentilerin ve çürüğün sert tabaka hissedilene kadar el aletleri yardımı ile uzaklaştırımasının ardından, 30 sn ozon uygulaması önerilmektedir. Ozon uygulanan lezyon yüzeyine uzun dönem fluorid ve mineral salımı yapan bir CIS ile restorasyon tamamlanmaktadır. Bu modifiye atravmatik restorasyon tekniği (ART) ilk olarak Dr Julian Holmes ${ }^{18}$ tarafından rapor edilmiştir. Holmes'ün, ${ }^{18}$ ozon tedavisi ile birlikte ART uygulamasını geleneksel tedavilerle karşılaştırdığı in vivo bir çalışmada, 18 aylık takip periyodunun sonunda geleneksel uygulama yapılan dişlerin, \%30'unda pulpa nekrozu bulguları tespit edilirken; bu oran ozon tedavisi ve ART uygulanan dişlerde \%3 olarak rapor edilmektedir.

Abu-Salem ve ark. ${ }^{19}$ okluzal çürük gözlenen süt dişlerinde ozon tedavisinin erken dönem etkinliğini değerlendirmek amacı ile yaptıkları çalışmada; 10 ve 20 sn ozon uygulamasının hemen sonrasında DIAGNOdent ve elektronik çürük monitörü (ECM) değerlerinin azaldığı rapor edilmiştir.

Yine Abu-Salem ve ark. ${ }^{20} 42$ okluzal çürüklü süt dişi üzerinde yürüttüğü 6 ay takipli in vivo çalışmada, $10 \mathrm{sn}$ ozon uygulamasının etkinliği, çalışmanın başlangıcında, 3. ayında ve 6. ayında tekrarlanan DIAGNOdent, ECM, klinik değerlendirme ve lezyonun renk ve sertlik ölçümleri sonucuna göre değerlendirilmiş, DIAGNOdent ve ECM ölçümlerinin istatistiksel olarak anlamlı fark yaratacak düzeyde remineralizasyon yönünde geliştiği rapor edilmiştir.

Danhardt ve ark. ${ }^{6} 2003$ yılında yapmış oldukları çaışmada, 2-10 yaş arası kaygılı çocukların ve ailelerinin ozon tedavisi öncesi ve sonrası davranışlarını analiz etmişlerdir. Ailelerden alınan bilgiler sonucunda, \%75 çocuğun diş hekimine gelmeden önce korkulu oldukları, ozon tedavisi sonrasında korkularının azaldığı ve tüm çocukların bir dahaki görüşmeye mutlu geldiği belirtilmektedir. Illk seansın sonunda \%75 ailenin tekrar ozon tedavisi uygulamasını ve \%85'inin geleneksel 'oyma ve 
doldurma' işleminden daha fazla para ödemeyi kabul ettiği rapor edilmektedir.

\section{Kavitasyon oluşmamış pit ve fissür çürüklerinin tedavisi}

Abu-Naba'a ve ark. ${ }^{21,22}$ başlangıç düzeyinde pit ve fissür çürüğü gözlenen dişler üzerinde, 10 ya da 40 sn ozon uygulamasının etkinliğini araştırdıkları 3 ve 12 aylık takip zamanlarında yürüttükleri iki farkı in vivo çalışmada, lezyonlarda remineralizasyonun gözlendiğini rapor etmektedirler. Megighiam ve ark. 200 başlangıç düzeyinde pit ve fissür çürüğü gözlenen diş üzerinde, 10 sn ozon uygulamasının hemen sonrası ve 1 aylık takibini yaptıkları çalışmada, lezyonların \%50'sinden fazlasında tedavinin hemen sonrasında DIAGNOdent değerlerinde azalma saptandığını, 1. ayın sonunda bu oranın \%90 olduğunu bildirmektedirler. Holmes'ün ${ }^{23} 579$ başlangıç düzeyindeki pit ve fissür çürüğü gözlenen dişte; $10,20,30$ ya da 40 sn ozon uygulamasının 4 ve 12 aylık takibini yaptığı çalışmada; DIAGNOdent değerlerine göre klinik olarak \%99 oranında remineralizasyonun gerçekleştiği rapor edilmektedir. Benzer şekilde Atabek ve Öztaş ${ }^{24}$ ozon ve remineralize edici solüsyon uygulanan pit ve fissür çürüklerinin 6 aylık takibinde kontrol grubu ile istatistiksel olarak anlamlı farklılık yaratacak düzeyde remineralizasyonun gerçekleştiğini rapor etmişlerdir. Abu Naba'a ve ark. ${ }^{25}$ DIAGNOdent ölçümlerini histolojik kesitlerle karşılaştırarak, pit ve fissür çürüğü gözlenen çekilmiş dişler üzerinde $2 \times 10$ sn ozon uygulamasının etkinliğini araştırdıkları çalışmada da benzer şekilde ozon uygulamasının hemen ardından DIAGNOdent değerlerinde histolojik kesit incelemeleri ile korelasyon gösteren anlamlı düzeyde azalmanın oluştuğunu bulgulamıştır.

Abu-Naba'a ve ark. ${ }^{26}$ pit ve fissür çürükleri üzerinde yaptıkları in vivo bir çalışmada, 40 sn ozon tedavisinden 1 ay sonra pit ve fissür çürüklerinin \%62'sinde çürük ilerlemesinin durdurulduğu ve çürük oluşumunun tersine çevrildiği, kontrol grubu lezyonlarının \%39'unun aynı kaldığı, lezyonların \%61'inin kötüye gittiği rapor edilmiştir.

Ozon, daimi dişlerin erüpsiyonu sırasında fissür örtücü uygulamalarının yerine ya da fissür örtücü uygulamaları öncesinde ve çürük görülme riski yüksek olan popülasyonlarda koruyucu bir yöntem olarak uygulanabilmektedir. Mine yüzeyi bozulmuş, kavitasyon oluşmuş pit ve fissür çürüklerinde ya da kök yüzey çürüklerinde ise, ozonun remineralizasyon sağlamak amacı ile kullanımından sonra kavitenin uygun bir restoratif materyal ile restorasyonu önerilmektedir. Genellikle tercih edilen materyal CIS ya da kompozit olarak bildirilmektedir. ${ }^{1}$
Al Shorman ve ark. ${ }^{27}$ pit ve fissür çürüklerinin ozon tedavisi öncesi ve sonrasında hastaların davranışlarını inceledikleri çalışmada, hastaların tedaviyi kabulü ve bakış açılarının olumlu yönde değiştiği belirtilmektedir.

\section{Derin çürük lezyonlarının tedavisi}

Derin çürük lezyonları, yalnızca ozon kullanılarak tedavi edilememekte, ozon tedavisinin geleneksel tedavilerle kombine bir şekilde kullanımı ile başarı sağlanabilmektedir. Yumuşak eklentiler, desteksiz mine dokusu ve mümkünse enfekte dentin sert doku hissedilinceye kadar kaldırımakta, ozon tedavisi uzun süre ile 2-3 kez tekrarlanarak uygulanmakta, remineralize edici solüsyon tatbikine geçilmekte ve lezyon yüzeyi mineral salımı yapan bir CIS ile restore edilerek 3-4 ay sonra daimi restorasyon yapılmaktadır. ${ }^{1}$

Aproksimal yüzeylerin tedavisinde ozon kullanımı sonrası, CIS restorasyon uygulamasının geleneksel yöntemler ile karşılaştırıldığı çalışmada 9 ay süresince, ozon tedavisi uygulanan grupta remineralizasyonun gerçekleştiği rapor edilmektedir. ${ }^{28}$ Öte yandan Baysan ve Beighton ${ }^{29} 2007$ yılında yaptıkları bir başka çalışmada, okluzal çürüklü çekilmiş dişlerde 40 sn ozon ya da yalnızca hava uygulamasının demineralize dentine ulaşan bakteri sayısı üzerindeki etkinliğini araşıımışlar ve ozonun dentin üzerindeki etkinliğini zayıf olarak rapor etmişlerdir.

Nogales ve ark. ${ }^{10}$ çürük lezyonlarının derinliğine yönelik ozonun doğru uygulama zamanı konusunda daha fazla çalışma yapılması gerekliliği vurgulamıştır. Yapılan çalışmalar sonucunda ozon uygulamalarının mine altındaki dentine etkili bir şekilde ulaşamadığı, direkt dentin üzerine uygulanan çalışmalarda ve küçük lezyonlarda başarının büyük lezyonlara göre arttığı ifade edilmektedir. $11,29,30$

\section{Kök yüzey çürük lezyonlarının tedavisi}

Holmes'ün ${ }^{18}$ başlangıç kök yüzeyi çürüklerinde ozon uygulaması sonrası DIAGNOdent değerleri kullanarak klinik takiplerini yaptığı çalışmada, çürük ilerlemesinin durdurulduğu ve remineralizasyonun gerçekleştiği rapor edilmektedir.

Baysan ve ark. ${ }^{11,31,32} 10$ ya da 20 sn ozon uygulaması sonrasında başlangıç kök yüzey çürüklerinde mikroorganizma sayısındaki değişimi araştırdıkları çalışmalarda, mikroorganizma sayılarının ve takip zamanlarında tekrarlanan DIAGNOdent değerlerinin anlamlı farkııık yaratacak düzeyde azaldığı, bununla birlikte çürük lezyonlarında remineralizasyon sürecinin başlatıldığı bildirilmektedir.

Sonuç olarak araştırmacılar küçük ve kavitasyon oluşmamış lezyonlardaki antibakteriyal etkinin daha yüksek; geniş, kavitasyon oluşmuş, dentindeki ve diş etine 
yakın lezyonlardaki etkinin daha zayıf olduğunu rapor etmişlerdir. ${ }^{10,11,33}$ Baysan ve Lynch, ${ }^{30}$ bu sonucu küçük ve kavitasyon oluşmamış çürük lezyonlarının daha az karyojenik mikroorganizma içerdiğini bildirerek açıklamışıı. Ayrıca büyük lezyonların güçlü yapısı ve demineralize dentindeki organik içeriğin daha fazla olmasının, ozon gazının etkinliğini sınırladığı bildirilmiştir.

Holmes, ${ }^{18}$ yürüttüğü çalışmalar sonucunda ozon gazının güçlü antibakteriyel özelliğinin yanı sıra diş hekimliği pratiğine kazandırmış olduğu bir diğer avantajın, güçlü okside edici özelliği sayesinde çürük lezyonundan etkilenen dokunun uzaklaştırımadan, remineralizasyon döngüsünün desteklenebileceği şeklinde ifade etmektedir. Araştırmacılar ozon uygulamasından sonra oluşacak ortamın, düşük dozlarda fluorid varlığında bile remineralizasyonu kolaylaştıracağı ve hipermineralizasyon seviyesini arttıracağı konusunda hemfikirdir. ${ }^{1,11,30}$

\section{SonUC}

Ozon uygulamaları sonrasında oluşan hipermineralize diş dokusunun sonraki yeni asit ataklarına karşı daha dirençli bir yapı kazanacağı, aynı zamanda yöntemin ağrısız, hızlı, atravmatik, hasta kabulünün ve uyumunun yüksek olduğu göz önüne alındığında, ozon uygulamalarının çürük tedavisinde invaziv olmayan yaklaşımların amacına hizmet edebileceği düşünülmektedir.

Çıkar çatışması: Yazarlar bu çalışmayla ilgili herhangi bir çıkar çatışmalarının bulunmadığını bildirmişlerdir.

\section{KAYNAKLAR}

1. Lynch E. Ozone in dentistry. The revolution in dentistry. 1st ed. London: Quintessence Publishing; 2004. p.18-31.

2. Bocci V, Paulesu L. Studies on the biological effects of ozone 1. Induction of interferon gamma on human leucocytes. Haematologica 1990;75:510-5.

3. Bocci V. Ozone as a bioregulator. Pharmacology and toxicology of ozonetherapy today. J Biol Regul Homeost Agents 1996;10:31-53.

4. Millar BJ, Hodson N. Assessment of the safety of two ozone delivery devices. J Dent 2007;35:195-200.

5. Megighiam GD, Bertolini L, De Pieri A, Lynch E. In vivo treatment of occlusal caries with ozone: One and two Months' effect with light-induced fluorescence (QLF) as diagnostic methods [abstract]. J Dent Res 2003;82(Spec Iss B):B354.

6. Dähnhardt JE, Jaeggi T, Lussi A. Treating open carious lesions in anxious children with ozone. A prospective controlled clinical study. Am J Dent 2006;19:267-70.

7. Abu-Naba'a L, AL Shorman H, Lynch E. In vivo treatment of occlusal caries with ozone: Immediate effect and correlation of diagnostic tools. Caries Res 2002;36:189.

8. Bader JD, Shugars DA. A systematic review of the performance of a laser fluorescence device for detecting caries. J Am Dent Assoc 2004;135:1413-26.

9. Lussi A, Longbottom C, Gygax M, Braig F. Influence of professional cleaning and drying of occlusal surfaces on laser fluorescence in vivo. Caries Res 2005;39:284-6.
10. Nogales CG, Ferrari PH, Kantorovich EO, Lage-Marques JL. Ozone therapy in medicine and dentistry. J Contemp Dent Pract 2008;9:75-84.

11. Baysan A, Whiley RA, Lynch E. Antimicrobial effect of a novel ozone- generating device on micro-organisms associated with primary root carious lesions in vitro. Caries Res 2000;34:498-501.

12. Rickard GD, Richardson R, Johnson T, McColl D, Hooper L. Ozone therapy for the treatment of dental caries. Cochrane Database Syst Rev 2004;3:CD004153.

13. Featherstone JD. The science and practice of caries prevention. J Am Dent Assoc 2000;131:887-99.

14. Atabek D, Çınar Ç, Öztaş N, Akca G, Suludere Z. In vitro antibacterial efficiency of irrigation regimens against biofilm of Enterococcus faecalis. J Dent Fac Atatürk Uni 2013;21:165-71.

15. Lynch E. Antimicrobial management of primary root carious lesions: a review. Gerodontology 1996;13:118-29.

16. Lynch E, Smith E, Baysan A, Silwood CJ, Mills B, Grootveld M. Salivary oxidising activity of a novel anti-bacterial ozone-generating device. J Dent Res 2001;80:13.

17. Baysan A, Lynch $E$. The use of ozone in dentistry and medicine. Part 2. Ozone and root caries. Prim Dent Care 2006;13:37-41.

18. Holmes J. Clinical reversal of decay using ozone. Lynch E, ed. The revolution in Dentistry. 1st ed. London: Quintessence Publishing; 2004. p.118-231.

19. Abu-salem OT, Marashdeh MM, Lynch E. Immediate effect of ozone on occlusal caries of primary teeth. J Dent Res 2003;82:C535.

20. Abu-salem OT, Marashdeh MM, Lynch E. Efficacy in treatment of occlusal caries in primary teeth. J Dent Res 2003;82:B136.

21. Abu-Naba'a L, Al-Shorman H, Lynch E. Ozone treatment of primary occlusal pit and fissure caries (POPFC): 12 mounths clinical severity changes. Caries Res 2003;37:272.

22. Abu-Naba'a L, Al-Shorman H, Lynch E. 6-month clinical indices changes after treatment pit and fissure caries (PFC). J Dent Res 2003;82:B135.

23. Holmes J. Clinical reversal of occlusal pit and fissure caries using ozone. J Dent Res 2003;82:B354.

24. Atabek D, Oztas N. Effectiveness of ozone with or without the additional use of remineralizing solution on non-cavitated fissure carious lesions in permanent molars. Eur J Dent 2011;5:393-9.

25. Abu-Naba'a L, Al-Shorman H, Lynch E. The effect of ozone application on fissure caries QLF readings. J Dent Res 2002;81: A389.

26. Abu-Naba'a L, Al-Shorman $H$, Lynch E. Clinical indices changes in ozone treatment of pit and fissure caries. J Dent Res 2003;82: 1173.

27. Al Shorman H, Abu-Naba'a L, Lynch E. Patient's attitude to treatment of pit and fissure caries with ozone. Caries Res 2002;36:187.

28. Clifford C. Successful use of air abrasion in conjuction with ozone treatment. J Dent Res 2003;82:B2747.

29. Baysan A, Beighton D. Assessment of the ozone-mediated killing of bacteria in infected dentine associated with non-cavitated occlusal carious lesions. Caries Res 2007;41:337-41.

30. Baysan A, Lynch E. Effect of ozone on the oral microbiota and clinical severity of primary root caries. Am J Dent 2004;17:56-60.

31. Baysan A, Lynch E, Grootveld M. The use of ozone for the management of primary root carious lesions. Albrektsson T, ed. Tissue preservation and caries treatment. 1st ed. London: Quintessence Book; 2001. p.49-67.

32. Baysan A, Lynch $E$. The use of ozone in dentistry and medicine. Prim Dent Care 2005;12:47-52.

33. Atabek D, Sungurtekin E, Öztaş N. Yüksek mineral içerikli ajanların ozon tedavisi ile kombine kullanımının fissür çürükleri üzerine etkisi. GÜ Diş Hek Fak Derg 2012; 29:165-71. 


\section{Application of ozone in dental caries treatment}

\section{Abstract}

In recent years within the scope of 'preventive approach in dentistry' or 'non-invasive approaches' ozone applications as a new treatment modality has been raised. The oxidation reaction resulting from the presence of ozone molecule makes ozone a strong biocidal agent which destroys the cell walls of bacteria. The aim of this review was to introduce the basic properties of ozone and its effects on the dynamics of dental caries and to provide information on the usage of ozone according to caries types.

KEYWORDS: Ozone; dental caries; tooth remineralization 